\title{
Competence in Haemophilus influenzae. A Role for Inosine and Lactate in the Primary Cell- deoxyribonucleic Acid Attachment Reaction
}

\author{
By J. M. RANHAND* \\ Department of Microbiology, University of Cincinnati \\ College of Medicine, Cincinnati, Ohio 452 I9, U.S.A.
}

(Accepted for publication I5 April 1969)

\begin{abstract}
SUMMAR Y
Cells of Haemophilus influenzae grown with or without competence promoting factors, inosine and lactate, were compared in their ability to bind deoxyribonucleic acid (DNA) and to undergo a genetic transformation. It was found that cells grown with the above factors bound $70 \%$ of the ${ }^{14} \mathrm{C}$-labelled DNA and transformed to a relatively high level (I.4 to $2.5 \%$ ). Cells grown without the factors bound only $8 \%$ of the ${ }^{14} \mathrm{C}$-labelled DNA and transformed to a low level (0.01 \% or less).

It is suggested from these studies that during growth cells of Haemophilus influenzae use inosine and lactate either to form or modify that portion of the cell surface that can later become involved in binding DNA.
\end{abstract}

\section{INTRODUCTION}

Ranhand \& Herriott (I966) reported that the development of competence in Haemophilus influenzae was dependent on the presence of both inosine and lactate during growth (phase I). It was unknown at that time whether these factors influenced the primary cell-DNA reaction or the recombinational events that follow the uptake of DNA. This report shows, by comparing directly the extent of transformation and the amount of ${ }^{14} \mathrm{C}$-labelled DNA bound by cells grown with or without inosine and lactate, that it is the primary cell-DNA reaction that is affected.

\section{METHODS}

Organism and transforming DNA. Haemophilus influenzae strain RD and the method used for preparing transforming DNA from cells that were resistant to more than streptomycin $2 \mathrm{mg} . / \mathrm{ml}$. were described by Goodgal \& Herriott (I96I). DNA derived from cells that were resistant to novobiocin (cathomycin) $25 \mu \mathrm{g}$. $/ \mathrm{ml}$. was a gift from Dr R. M. Herriott, Johns Hopkins University, Baltimore, Md.

Phase I growth medium and cultural conditions. The trypticase growth medium containing glucose (TCMG) and the cultural conditions used were as previously described (Ranhand \& Lichstein, I966). In one experiment (Table 2) glucose was deleted from the growth medium (TCM). When glucose, lactate and inosine were

* Present address: Laboratory of Microbiol ogy, National Institute of Allergy and Infectious Diseases, Bethesda, Maryland 20014, U.S.A. 
deleted from the medium, adenosine $660 \mu \mathrm{g} . / \mathrm{ml}$. was added. This addition was found necessary for growth.

Phase 2 medium for the development of competence and transformation procedures. The phase 2 medium used for the development of competence was essentially that of Spencer \& Herriott (1965) modified with $0.05 \%$ acid hydrolysed casein (Ranhand \& Lichstein, 1966). The transformation procedures used were as described by Ranhand \& Lichstein (1966).

${ }^{14} \mathrm{C}$-labelled $D N A .{ }^{14} \mathrm{C}$-labelled DNA was prepared from cells grown in TCM containing inosine, $\mathrm{I} \cdot 32 \mathrm{mg} . / \mathrm{ml}$, lactate $660 \mu \mathrm{g} . / \mathrm{ml}$. and thymidine- $-2-{ }^{14} \mathrm{C} 0.05 \mu \mathrm{c} . / \mathrm{ml}$. by methods already described (Goodgal \& Herriott, 196I). The thymidine had a specific activity of $30 \mathrm{mc}$./mmole and was obtained from the New England Nuclear Corp., Boston, Mass. The high inosine concentration, suggested by Dr R. M. Herriott, allows for more efficient utilization of the thymidine. The final DNA preparation had an approximate specific activity of $6 \times 10^{3}$ c.p.m. $/ \mu \mathrm{g}$. and was used without prior dialysis.

Radioactivity determinations. Radioactivity was measured with a Packard Tri-Carb liquid scintillation spectrometer model No. 3003 using Bray's solution (1960). Background was subtracted from the values presented.

\section{RESULTS}

Kinetics of the development of competence. Figure I shows the kinetics of the development of competence, measured by transformation to streptomycin resistance, by cultures of Haemophilus influenzae grown in TCMG with or without inosine and lactate. Cells grown with the factors developed competence rapidly and reached a maximum value of $2.5 \%$ at about $100 \mathrm{~min}$. (The per cent transformation equals the number of transformed cells $/ \mathrm{ml} \times 100$ divided by the number of viable cells $/ \mathrm{ml}$.) Cells grown without inosine and lactate did not develop competence appreciably over the $100 \mathrm{~min}$. tested and transformed to a maximum value of $0.01 \%$. In both cultures the viable count increased slightly.

Although not shown, a similar result was obtained when a completely defined medium described by Ranhand (1964) was used for phase I.

Effect of inosine and lactate on DNA binding to cells. To achieve successful transformation at least two steps must occur: (i) the attachment of DNA to the cells and (ii) the incorporation of the DNA into the resident genome. Because the results presented in Fig. I did not reveal why cells grown without inosine and lactate did not transform, two experiments were done to determine which of the above steps was influenced by inosine and lactate.

The first experiment was designed to show the amount of DNA taken up by cells by measuring the amount of residual (unreacted) DNA left in the supernatant fluid. If cells grown without inosine and lactate were capable of taking up DNA, for example, they were competent but not able to integrate the DNA into their genome, then most, if not all, of the DNA added should have been removed from the reaction mixtures under the conditions described below. On the other hand, if the cells could not take up DNA, then the unreacted DNA should have been available for transforming other fully competent cells.

Cells were grown with or without inosine and lactate and were put through a 
competence development procedure as previously described (Ranhand \& Lichstein, 1966). A limiting amount of DNA ( $\mathrm{I} \times \mathrm{IO}^{-3} \mu \mathrm{g} . / \mathrm{ml}$., determined independently) carrying the streptomycin resistance marker was added to these cells and transformation to streptomycin resistance was determined in the usual manner. After removing a test sample $(0 \cdot \mathrm{I} \mathrm{ml}$.), competent cells that were already resistant to novobiocin were

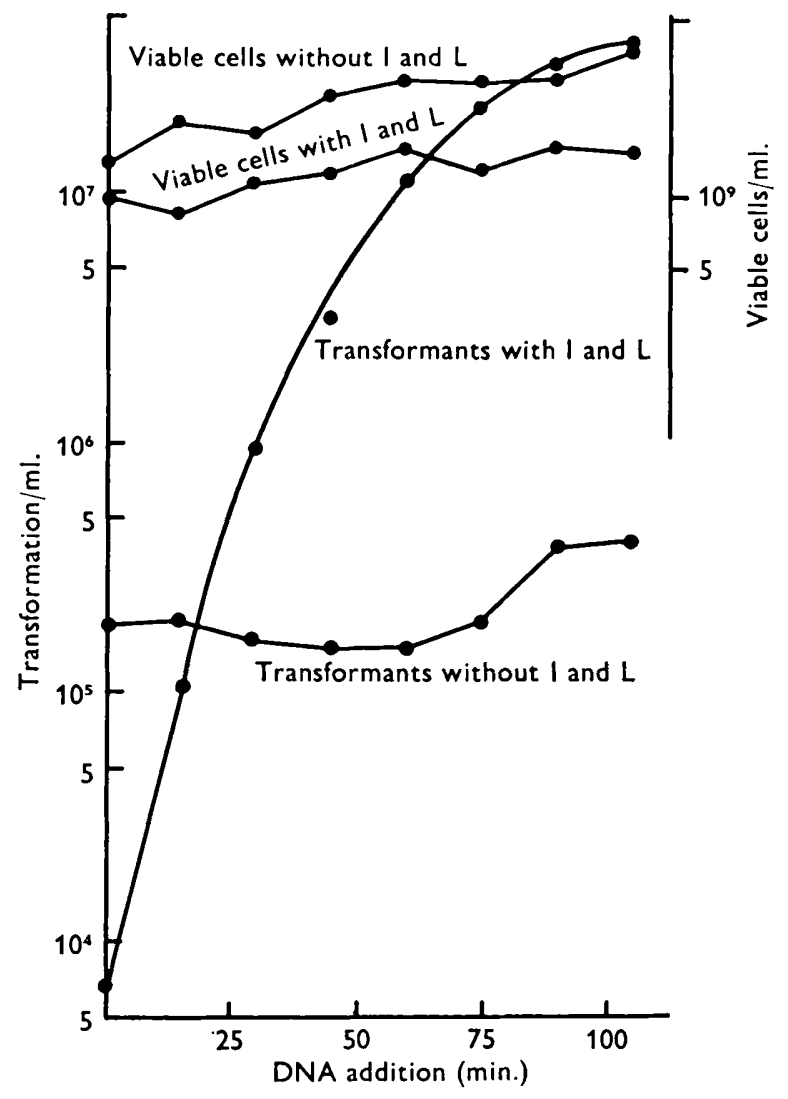

Fig. I. Kinetics of the development of competence. Cells wero grown with or without inosine (I) $330 \mu \mathrm{g} . / \mathrm{ml}$. and lactate (L) $330 \mu \mathrm{g} . / \mathrm{ml}$. in TCMG and diluted into the competence medium (Ranhand \& Lichstein, 1966). At the indicated times, DNA I $\mu \mathrm{g}$. carrying the streptomycin-resistant marker and 8-azaguanine $5 \mu \mathrm{g}$. were added $/ \mathrm{ml}$. The cells were shaken for $30 \mathrm{~min}$. after the additions, at which time they were diluted and plated as described previously (Ranhand \& Lichstein, I966).

added to the reaction mixtures and residual DNA carrying the streptomycin marker was assayed by observing the number of cells resistant to both streptomycin and novobiocin. The use of novobiocin-resistant competent cells for the second transformation reaction eliminated a potentially large background of streptomycin-resistant cells. In other experiments, samples were heated to $60^{\circ}$ for $30 \mathrm{~min}$. before assaying the residual DNA, and the results obtained were similar. Furthermore, analogous results werealso obtained when the defined medium described by Ranhand (1964) was used for phase $\mathrm{I}$. 
The results of this experiment (Table I) show that cells grown with inosine and lactate removed almost $100 \%$ of the input DNA, indicated by the low level of streptomycin novobiocin-resistant cells obtained (column 5), whereas cells grown without inosine and lactate removed only $5 \%$. These values are based on the number of transformations $/ \mathrm{ml}$. to streptomycin resistance observed $\left(2 \cdot \mathrm{I} \times 10^{4} / \mathrm{ml}\right.$.) using competent novobiocin-resistant cells and DNA I $\times \mathrm{IO}^{-3} \mu \mathrm{g}$. $/ \mathrm{ml}$.

Table I. The effect of inosine and lactate on DNA uptake

\begin{tabular}{|c|c|c|c|c|c|c|}
\hline Supplements to TCMG & $\begin{array}{c}\text { DNA } \\
(\mu \mathrm{g} . / \mathrm{ml})\end{array}$ & $\begin{array}{c}\text { Transfor- } \\
\text { mations } \\
\text { /ml. to } \\
\text { str-r } \\
\times 10^{-3}\end{array}$ & $\begin{array}{c}\text { Viable } \\
\text { cells } / \mathrm{ml} \\
\times 10^{-0}\end{array}$ & $\begin{array}{l}\text { Transfor- } \\
\text { mations } \\
\text { /ml. to } \\
\text { str-r } \\
\text { among } \\
\text { nov-r cells }\end{array}$ & $\begin{array}{l}\text { Transfor- } \\
\text { mation* } \\
(\%)\end{array}$ & $\begin{array}{c}\text { Residual } \\
\text { DNA } \\
(s t r-r) \\
(\%)\end{array}$ \\
\hline Inosine and lactate & 10 & 150 & $I \cdot I$ & - & $1 \cdot 4$ & - \\
\hline Inosine and lactate & $10^{-3}$ & 0.44 & $2 \cdot 0$ & 50 & - & 0.24 \\
\hline None & 10 & $1 \cdot 7$ & $3 \cdot 3$ & - & 0.01 & - \\
\hline None & $10^{-3}$ & 0.028 & $3 \cdot 4$ & $2 \times 10^{4}$ & - & 95 \\
\hline
\end{tabular}

Cells were grown in a trypticase medium containing glucose (TCMG) with or without inosine 330 $\mu \mathrm{g} / \mathrm{ml}$. and lactate $330 \mu \mathrm{g} . / \mathrm{ml}$. and were put through a competence development procedure as previously described (Ranhand \& Lichstein, 1966). DNA was added at the indicated concentrations for $30 \mathrm{~min}$., at which time $0.1 \mathrm{ml}$. of culture was used to assay the number of transformations to streptomycin resistance (str-r). The remainder of the reaction mixtures were kept at $4^{\circ}$, and on the following day competent novobiocin-resistant (nov-r) cells were added to them. Residual DNA was assayed by observing the number of cells that were both nov-r and str-r using standard procedures. The control consisted of competent nov-r cells and str-r DNA $10^{-3} \mu \mathrm{g} . / \mathrm{ml}$., which gave $2.1 \times 10^{4} \mathrm{str}-r$ transformants $/ \mathrm{ml}$. This value was taken as the $100 \%$ value to calculate the residual DNA present in column seven.

* Number of transformed colonies $/ \mathrm{ml} . \times 100$ divided by number of viable cells $/ \mathrm{ml}$.

Table 2. The uptake of ${ }^{14} \mathrm{C}$-labelled DNA by Haemophilus influenzae grown with or without inosine and lactate

\begin{tabular}{|c|c|c|c|c|}
\hline \multirow[b]{2}{*}{ Supplements to TCM } & \multirow[b]{2}{*}{$\begin{array}{l}\text { DNA addition } \\
\text { (min.) }\end{array}$} & \multirow[b]{2}{*}{$\begin{array}{l}\text { DNAase } \\
(5 \mu \mathrm{g} . / \mathrm{ml} .)\end{array}$} & \multicolumn{2}{|c|}{$\%$ radioactivity } \\
\hline & & & Supernatant & Cells \\
\hline None & 0 & - & 87 & 12 \\
\hline None & 0 & + & 97 & 3 \\
\hline Inosine and lactate & 0 & - & $9 I$ & 9 \\
\hline Inosine and lactate & 0 & + & 99 & I \\
\hline None & 80 & - & $\begin{array}{l}99 \\
92\end{array}$ & 8 \\
\hline None & 80 & + & 97 & 3 \\
\hline Inosine and lactate & 80 & - & 29 & 71 \\
\hline Inosine and lactate & 80 & + & 68 & 32 \\
\hline
\end{tabular}

Cells were grown in a trypticase medium minus glucose (TCM) with or without inosine $660 \mu \mathrm{g} . / \mathrm{ml}$. and lactate $660 \mu \mathrm{g} . / \mathrm{ml}$. (Methods) and treated as described previously (Ranhand \& Lichstein, 1966). At zero-time, cells were diluted into the phase 2 medium containing 8 -azaguanine $5 \mu \mathrm{g}$. $/ \mathrm{ml}$. (Ranhand \& Lichstein, 1969) and ${ }^{14} \mathrm{C}$-labelled DNA $0.05 \mathrm{ml}$. (0.066 $\mu \mathrm{g} ; 342$ c.p.m.). They were shaken for $30 \mathrm{~min}$. after the addition of the DNA, and pancreatic deoxyribonuclease (DNAse) was added when required for $5 \mathrm{~min}$. The cells were centrifuged, and the supernatant fluids were removed. Cell pellets were resuspended in $1.0 \mathrm{ml}$. of water. Appropriate samples were counted in the liquid scintillation spectrometer. The same procedure was followed at $80 \mathrm{~min}$.

The second experiment was designed to test whether cells grown without inosine and lactate bound any DNA at all. ${ }^{14} \mathrm{C}$-labelled DNA was added to cells grown with or without inosine and lactate at zero-time and at $80 \mathrm{~min}$. in phase 2. The results (Table 2) show that both cultures reacted poorly with DNA at zero-time. At $80 \mathrm{~min}$, however, 
only cells grown with inosine and lactate reacted with DNA and adsorbed about $70 \%$ of it. On the other hand, cells grown without inosine and lactate adsorbed only $8 \%$. Furthermore, only cells grown with the factors bound an appreciable amount of DNA irreversibly $(45 \%)$ as determined by its resistance to pancreatic deoxyribonuclease.

The results obtained from these two experiments clearly showed that inosine and lactate did indeed influence the binding of DNA to cells. However, the role, if any played by inosine and lactate on the recombination events remains to be found.

\section{DISCUSSION}

In an earlier report, Ranhand \& Lichstein (1966) suggested that inosine and lactate were functioning at or near the DNA binding site. In addition, they showed that these sites could be equally destroyed by periodate when cells were treated either at zerotime (low competence) or at $80 \mathrm{~min}$. (high competence) in phase 2. This result was

A. Cells grown with inosine and lactate
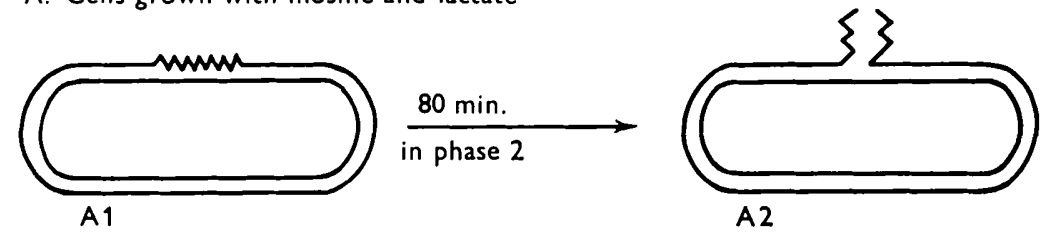

B. Celis grown without inosine and lactate

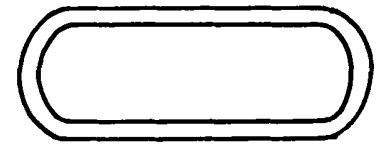

B1
$80 \mathrm{~min}$

in phase 2

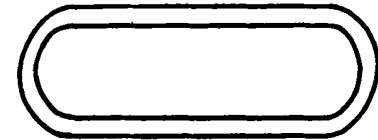

B2

Fig. 2. A model comparing Haemophilus influenzae cells grown with or without inosine and lactate. A1: Premature DNA binding site presumably derived from the metabolism of inosine and lactate during growth is present but it cannot yet react with DNA; however, it can be inactivated by periodate (Ranhand \& Lichstein, 1966). There are about 27 such sites per cell (Barnhart \& Herriott, 1963). A2: After $80 \mathrm{~min}$. in phase 2 the premature site becomes modified so that it can now react with DNA. This modification appears to be dependent on protein synthesis (Ranhand \& Lichstein, 1969). These sites can also be destroyed with periodate. BI : Premature DNA binding site not present due to absence of inosine and lactate during growth. B2: No DNA sites present; therefore, cells are non-competent.

interpreted to mean that inosine and lactate contributed to a site (presumably on the cell surface) that later became modified into a DNA binding site upon further incubation in phase 2. The results presented in Table 2 may further support this hypothesis because at zero-time in phase 2 cells grown with or without inosine and lactate do not bind large amounts of DNA.

Although the exact role played by inosine and lactate is as yet unknown, an interpretation of the data is presented diagrammatically in Fig. 2. Cells grown with inosine 
and lactate have a site(s) on their surface that is important for the development of competence but it is not reactive towards DNA at zero-time in phase 2, that is, it cannot bind DNA (Fig. $2 \mathrm{AI}$ ). Incubation for $80 \mathrm{~min}$. in phase 2 , however, causes the modification of these pre-existing sites into DNA binding sites.(Fig. 2 A2) presumably by processes that require protein synthesis (Ranhand \& Lichstein, 1969). Cells grown without inosine and lactate lack these sites or modifications (Fig. $2 \mathrm{BI}$ ), and therefore cannot react with DNA at 80 min. in phase 2 (Fig. 2 B2).

Unfortunately, studies made with lactate- $\mathrm{U}-{ }^{14} \mathrm{C}$ and inosine $-8-{ }^{14} \mathrm{C}$ have not yet revealed their specific functions.

I express deep gratitude to Dr H. C. Lichstein and Dr J. C. Loper for their encouragement and advice during my predoctoral years.

This work was supported in part by research grants awarded to Dr H. C. Lichstein from the National Science Foundation (GB 2595 and GB 6793), the Office of Naval Research (NR-I03-555), and a Public Health Service training grant (5TI-GM I255) from the National Institutes of Health. The work was submitted in partial fulfilment of the requirements for the degree of Doctor of Philosophy, University of Cincinnati.

\section{REFERENCES}

Barnhart, B. J. \& Herriotr, R. M. (I963). Penetration of deoxyribonucleic acid into Hemophilus influenzae. Biochem. biophys. Acta 76, 25.

Bray, G. A. (1960). A simple efficient liquid scintillator for counting aqueous solutions in a liquid scintillator counter. Analyt. Biochim. I, 279.

Goodgal, S. H. \& Herriott, R. M. (196I). Studies on transformations of Hemophilus influenzae. I. Competence. J. gen. Physiol. 44, I 201.

RANHAND, J. M. (1964). Factors required by Haemophilus influenzae that promote the subsequent development of competence. M.S. Thesis, Johns Hopkins University, Baltimore, Md.

RANHAND, J. M. \& Herriort, R. M. (1966). Inosine and lactate: Factors critical during growth for development of competence in Haemophilus influenza. Biochem. biophys. Res. Commun. 22, 59I.

RanhaND, J. M. \& Lichstein, H. C. (1966). Periodate inhibition of transformation and competence development in Haemophilus influenzae. J. Bact. 92, 956.

Ranhand, J. M. \& Lichstein, H. C. (1969). Effect of selected antibiotics and other inhibitors on competence development in Haemophilus influenzae. J. gen. Microbiol. 55, 37.

SPENCER, H. T. \& HERRIOTT, R. M. (1965). Development of competence of Haemophilus influenzae. J. Bact. 90, 9 I I. 